\title{
フィリピン人外鼻の性的二型の三次元的研究
}

\author{
吉田佳子近 藤 信太郎 \\ 浜田立太若月 英三 \\ 昭和大学歯学部第一口腔解剖学教室 (主任: 若月英三教授)
}

〔受付: 平成 5 年 12 月 15 日〕

\section{Three-dimensional measurement on sexual dimorphism of the Filipino Nose}

\author{
Keiko Yoshida, Shintaro Kondo, \\ Ryuta Hamada and Eizo Wakatsuki \\ The First Department of Oral Anatomy, School of Dentistry, Showa University \\ (Chief : Prof. Eizo Wakatsuki) \\ 1-5-8 Hatanodai, Shinagawa-ku, Tokyo, 142, Japan \\ (Accepted for publication: December 15, 1993)
}

Key words: Filipino/Japanese/nose size/dorsalnose/moiré

\begin{abstract}
This study was carried out with the goal of clarifying the shape of Filipino male and female's noses. The subjects were 61 Filipino males aged 18 to 38 and 123 females aged 18 to 35 .

Measurements of the nose were taken from moiré photographs. Dorsal nose shapes and nose roof shapes were each divided into 5 categories.

In the categories of length, breadth, depth and dorsal nasal length, male noses were notably larger than female noses. The nasal angle of the female nose was greater than that of the male. In comparison with female noses, male noses showed a higher B-D index, but a lower $L-B$ index.

In dorsal nose shape, male noses showed a high frequency of straight and concave types while the concave type appeared with a high frequency in female noses. Nose roof shapes with no particularly striking features were frequent for both males and females. Fifty \% of the female noses, however, appeared in the underdeveloped category. In dorsal nose and nose roof shapes, type 5 was the characteristic Filipino nose shape.

The average nasal length of Filipino was less than that of the Japanese, but the average breadth was larger. The dorsal nose shape was also more frequently concave than that of the Japanese. Well-developed nose roofs were rarer among the Filipino than among the Japanese. Specially, Filipino females had a higher frequency of underdeveloped nose roof types than Japanese females.

In conclusion, compared to Japanese noses, Filipino noses display the characteristics of the southern nose type. These characteristics were particularly prominent in Filipino female's noses.
\end{abstract}

广 142 東京都品川区旗の台 1-5-8 
抄録：フィリピン人男女の外率形態について検討した。方法は，計测学的検討と，率背ならびに䀮屋の形態を 5 型に分類し，その出現率による検討を行った。

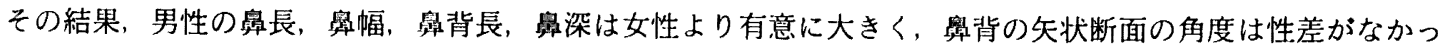

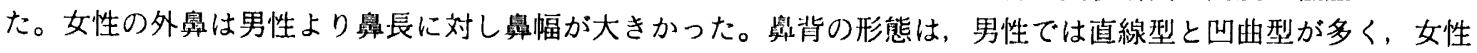
では凹曲型が多かった。鼻屋の形態は, 男性より女性の方が鼻屋の発達が悪かった。分類型のTYPE 5 はフィリ ピン人に特徵的形態であるが、特に女性で䫓著にみられた。

日本人と比べると,フィリピン人の鲎長は日本人より小さく，畧幅は大きかった。フィリピン人の鼻背形態は, 日本人より凹曲型が多く，鼻屋の発達は日本人より恶かった。鼻指数の分類では, フィリピン人は広鼻に属し， 日本人は中鼻に属していた。以上より,フィリピン人の外鼻は南方系の特徵を備えていた。

\section{緒言}

外鼻はその形態が特徵的な形を示すので, 従来よりさ まざまな方法で観察されてきた。

Martin, Topinard は鼻高, 鼻幅などから算出した指数 を基準として外鼻の分類を行い, また, Topinard, Bertillon, Bean は鼻背, 鼻孔の形態の肉眼観察による分類を 行っている ${ }^{1.2)}$ 。本邦においても, 形態の分類, さらに, 分類型による性差, 地方差を検討する報告が多数みられ $3^{3 \sim 10)}$ 。これらの観察方法は現在も有用な方法として外 鼻形態の分類に取り入れられている。また，近年では， モアレ縞の走行を利用して, 外鼻の対称性の研究, 鼻背, 鼻屋の分類が行われている11.12)。

また，個人差はあるが，Huter による鼻側面観の分類 において, イギリス型, ドイツ型, ローマ型, アラビア 型などと表現され(3), そして, ローマ鼻, ギリシャ鼻, ア ラビア鼻など人種や民族の名がつけられている(14)ほど，

外鼻は人種や民族により特徵的な形態をとることで知ら れている。

著者らは, フィリピン人に関して, 頭顔面部の形態, 歯列弓形態，女性の外鼻形態の検討を行った ${ }^{15 \sim 19) 。 そ し ~}$ て,フィリピン人女性と日本人女性の外鼻形態を比較し た結果, フィリピン人は南方系の特徵を兼ね備えている と報告した。

フィリピン人は, Turner の説によると Sundadont の 特徵を備えているといわれている20)。Turner の仮説は, モンゴロイドは歯の形質から特徵ある 2 つの歯列, Sundadont と Sinodont に大別できるとするものである。こ の歯列に対応する人種は, Sundadont は東南アジア, イ ンドネシア, ポリネシアに分布し, Sinodont は中国, 日 本, シベリア, アメリカ大陸に分布するという。このよ うに, フィリピン人と日本人はモンゴロイド大人種であ るが，異なる集団に属しているので，人類学的な比較検 討をすることは，重要であると考えられる。このことか ら，モアレ縞を利用して，フィリピン男性のデータを加
え，特に人種差が顕著であるとされる外悬の形態を調査 して, フィリピン人の性差, 日本人との比較検討を行っ た。

\section{材料および方法}

\section{1. 材料}

タガログ語を使用する、マニラおよびマニラ近郊に在 住するフィリピン人男性 61 名 (18～35 歳), フィリピン 人女性 123 名（18～35 歳）を被験者とした。3 SDを越え た計測值は, デー夕処理からはずした。性差, 人種差の 検討には, 平均値の差の検定, $\chi^{2}$ 検定を使用した。

\section{2. 方法}

1) 顔面写真撮影

被験者の顔面正面モアレ写真の撮影は, 眼耳平面を基 準として, Fujinon moiré camera FM-3013 で行った。 フィルムはコダック Tri-X を使用し, 現像は増感現像を 行った。計測, 分類には, 10 倍に拡大した写真のトレー スを用いた。撮影時には実測值換算のためにスケールを 挿入した。

2 ) 計測項目 (Fig. 1)

計測は, 以下の項目について, トレースしたモアレ縞 上で行った。計測点, 基準点は, 嘉村 ${ }^{21)}$ の方法を参考とし た。

鼻 長：鼻根部最陥凹点から鼻下点までの距離。

鼻 幅：左右鼻翼間距離。

鼻 深：鼻根部最陥凹点から鼻尖点までのモアレ縞の 本数 $\times 2 \mathrm{~mm}$ (モアレ縞の間隔)。

鼻背の矢状断面の角度：モアレ縞から顔面の側面観を パソコンで図化。その状態の額とオトガイの 最突出点を結合させた面を基準面とした場合 の鼻背の角度。

鼻背長 : 鼻背の矢状断の角度から算出した鼻根部最陥 凹点から鼻尖点までの距離。

3 ) 指数の算出 

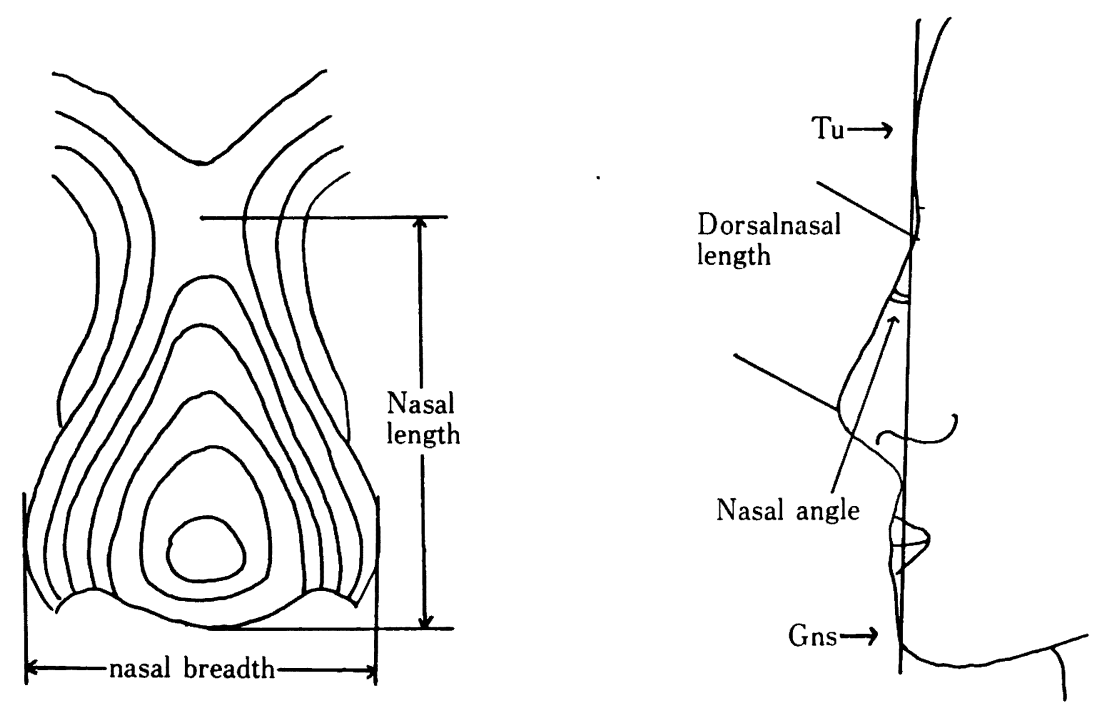

Fig. 1 Measuament of nasal length, nasal breadth, dorsalnasal length and nasal angle. Tu: The projection of forehead. Gns: The prujection of chin

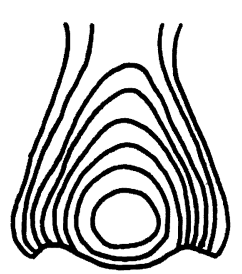

TYPE 1

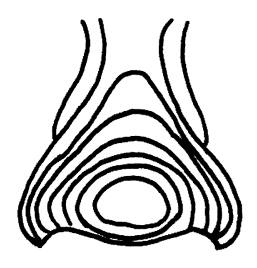

TYPE 2

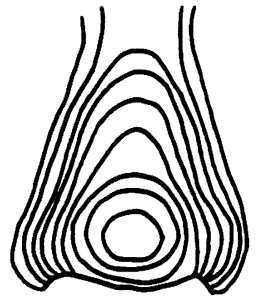

TYPE 3

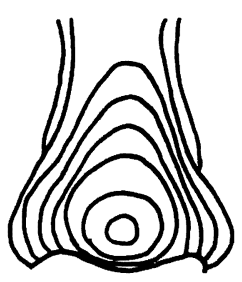

TYPE 4

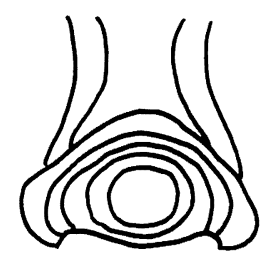

TYPE 5

Fig. 2 Type of the dorsalnose.

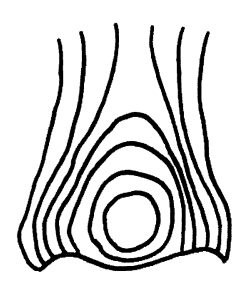

TYPE 1

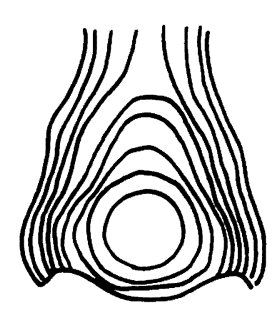

TYPE 2

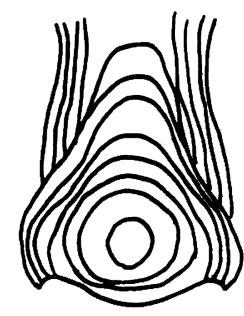

TYPE 3

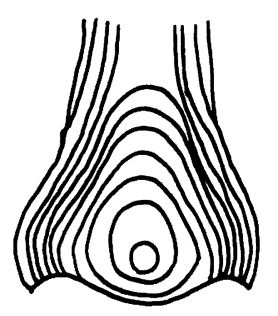

TYPE 4

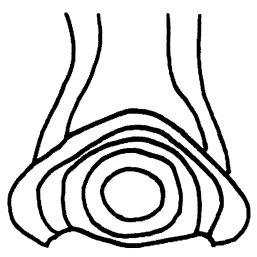

TYPE 5

Fig. 3 Type of the roof of a nose.

指数は以下の 2 項目を算出した。

鼻長幅指数：鼻幅 $/$ 鼻長 $\times 100$

鼻幅深指数：鼻深 $/$ 鼻幅 $\times 100$

4) 鼻背ならびに鼻屋のモアレ縞の走行による分類 鼻背, 鼻屋の形態の分類は, 古川ら ${ }^{11}$ の方法を参考とし た著者ら ${ }^{191}$ の方法で行った。

(1) 鼻背のモアレ縞の間隔による分類 (Fig. 2) TYPE 1 ：鼻背のモアレ縞が等間隔であるもの
TYPE 2 : 鼻根部付近の鼻背のモアレ縞の間隔が広い もの

TYPE 3 : 鼻背中央付近の鼻背モアレ縞の間隔が広い もの

TYPE 4：鼻尖部付近の鼻背モアレ縞の間隔が広いも の

TYPE 5：鼻背モアレ縞が鼻尖部付近に片寄って存在 し，丸みを带でてるもの 
Table 1 The basic statistical values of measurement and results of a t-test between sexes.

\begin{tabular}{lccccccccc}
\hline & \multicolumn{3}{c}{ Male $(\mathrm{N}=58)$} & \multicolumn{3}{c}{ Female $(\mathrm{N}=116)$} & \multicolumn{2}{c}{ t-test } \\
\hline & MN & SD & MAX & MIN & MN & SD & MAX & MIN \\
\hline Nasal length & 53.79 & 3.50 & 60.12 & 43.66 & 46.07 & 3.86 & 56.96 & 37.83 & $* *$ \\
Nasel breadth & 47.59 & 2.96 & 53.82 & 42.53 & 41.96 & 2.94 & 49.73 & 35.89 & $* *$ \\
Nasal depth & 15.38 & 2.38 & 22.00 & 10.00 & 11.26 & 2.70 & 18.00 & 6.00 & $* *$ \\
Nasal anggle & 26.81 & 3.28 & 33.57 & 20.07 & 27.92 & 4.26 & 40.66 & 16.50 & \\
Dorsalnasal length & 44.85 & 3.42 & 51.21 & 35.89 & 37.33 & 4.10 & 48.89 & 27.98 & $* *$ \\
L-B index & 88.84 & 7.80 & 109.65 & 72.42 & 91.62 & 8.99 & 109.90 & 64.23 & $*$ \\
B-D index & 28.62 & 4.22 & 40.82 & 20.55 & 26.81 & 6.00 & 41.68 & 12.66 & $*$ \\
\hline L-B index : nasal length-nasal breadth index & & & & $*: \mathrm{P}<0.05$ & $* * \mathrm{P}<0.01$ \\
B-D index : nasal breadth-nasfal depth index & & & & & &
\end{tabular}

Table 2 Type of the dorsalnose.

\begin{tabular}{lrccc}
\hline & Male & Female & $\chi^{2}$-test \\
\cline { 2 - 5 } & $\mathrm{n}(\%)$ & $\mathrm{n}(\%)$ & \\
\hline TYPE 1 & $26(42.62 \pm 6.33)$ & 23 & $(18.70 \pm 3.52)$ & $* *$ \\
TYPE 2 & $24(39.34 \pm 6.25)$ & 54 & $(48.90 \pm 4.47)$ & \\
TYPE 3 & $6(9.84 \pm 3.81)$ & $9(7.32 \pm 2.35)$ & $(0.00 \pm 0.00)$ & \\
TYPE 4 & $0(0.00 \pm 0.00)$ & $0(0.00)$ & \\
TYPE 5 & $5(8.20 \pm 3.51)$ & 37 & $(30.08 \pm 4.14)$ & $*$ \\
\hline
\end{tabular}

(2) 鼻屋の発達程度による分類 (Fig. 3)

TYPE 1 : 鼻屋の発達が悪く, モアレ縞の本数が少な いもの

TYPE 2 : 鼻屋が側方へ発達しているため, モアレ縞 が左右に突出しているもの

TYPE 3 : 鼻屋が発達し左右の鼻屋のモアレ縞がほほ 平行で，いわゆる鼻筋が通っているもの

TYPE 4 ：TYPE 1〜3, 5 のような著明な走行を示さ ないもの

TYPE 5 ：鼻背のモアレ縞が鼻尖部付近に片寄って存 在し，丸みを帯びているもの

\section{結 果}

1. 計測値, 指数値の結果 (Table 1)

計測項目では, 鼻背の矢状断面の角度を除いて男性が 女性より有意に大きい值を示した $(\mathrm{P}<0.01)$ 。鼻背の矢 状断面の角度は, 女性の方が男性より大きかったが有意 差は認められなかった。

指数項目では, 鼻長幅指数は女性の方が大きく, 鼻幅 深指数は, 男性が大きい值を示した $(\mathrm{P}<0.05)$ 。
Table 3 Type of the roof of a nose.

\begin{tabular}{|c|c|c|c|}
\hline & Male & Female & \multirow{2}{*}{$\chi^{2}$-test } \\
\hline & n (\%) & n (\%) & \\
\hline TYPE 1 & $2(3.28 \pm 2.28)$ & $26(21.14 \pm 3.68)$ & $* *$ \\
\hline TYPE 2 & $7(11.47 \pm 4.08)$ & $0(0.00 \pm 0.00)$ & $* *$ \\
\hline TYPE 3 & $2(3.28 \pm 2.28)$ & $4(3.25 \pm 1.60)$ & \\
\hline TYPE 4 & $45 \quad(73.77 \pm 5.63)$ & $56(45.53 \pm 4.49)$ & $* *$ \\
\hline TYPE 5 & $5(8.20 \pm 3.51)$ & $37(30.08 \pm 4.14)$ & $* *$ \\
\hline
\end{tabular}

\section{2. 鼻背のモアレ縞の走行による分類 (Table 2)}

男性は TYPE 1 が最も多くみられ, ついで TYPE 2 が多くみられた。女性はTYPE 2 が最も多くみられ, つ いで TYPE 5 が多くみられた。TYPE 1 は女性と比較 して男性が高い出現率を示し, TYPE 5 は男性と比較し て女性が高い出現率を示した。男性は多く出現する TYPE 1 と 2 で全体の約 $80 \%$ を占めた。女性では多く出 現する TYPE 2 と 5 が全体の $75 \%$ を占めた。男女とも に, TYPE 4 は出現していなかった。

\section{3 . 鼻屋の発達程度による分類 (Table 3)}

男性は TYPE 4 が最も多くみられ, 全体の約 $75 \%$ を 占めていた。ついで TYPE 2 が多くみられたが, わずか に $11.47 \%$ あ゙った。女性で最も多くみられたのは, 男性 と同じ TYPE 4 であったが, 出現率は全体の約 45\%を 占めるにとどまった。ついで TYPE 5 が多くみられた。 TYPE 2 は，女性では認められなかった。TYPE 2,4 は 男性が高い出現率を示したが, TYPE 1, 5 は女性が高い 出現率を示し, TYPE に性差がみられた。 
考察

外鼻の構成は，その上部は鼻骨によって支持され，そ の突出は鼻中隔軟骨によって決定されている。鼻背は外 側鼻軟骨により，鼻尖，鼻孔，鼻翼の一部は大鼻翼軟骨 によって形成されている。鼻根部の形は眉間部の発達に 関係しているといわれている1。

こうした特徵的外鼻を理解するために一般に形態の分 類が観察されてきた。分類方法は，指数を利用した定量 的な方法と肉眼観察による方法がある。肉眼観察の観察 基準は, 鼻背, 鼻孔, 鼻尖の形であり,これらに関連し て, 鼻背の角度, 鼻底面の形, 向き, 鼻根の陥凹状態が 検討されている年。

著者らは，モアレ縞を利用した分類方法と指数の両方 法でフィリピン人の外鼻形態について検討した。

\section{1.フィリピン人外鼾の性差}

フィリピン人の外鼻の計測值は，鼻背の矢状断面の角 度を除いて，男性が女性より大きかった。フィリピンの 頭顔面部の計測結果から, 男性の方が女性より顔面部は 大きいと報告されている ${ }^{16)}$ 。このことより外鼻の大きさ は顔面部と相関性があった。

鼻長幅指数は男性が女性より小さかった。すなわち， 女性の方が男性より鼻長に対して鼻幅が大きい形態をし ていると考えられる。日本人男女は, 鼻長幅指数に性差を 認めなかった ${ }^{22)}$ このことから,フィリピン人男女は鼻幅, 鼻長の関係に性差を認めた点で日本人と異なっていた。

フィリピン人は鼻幅深指数に性差を認めていることか ら，鼻幅に対しての鼻梁の深さは男性の方が女性より大 きかった。これは，日本人男女 ${ }^{22)}$ と同様であった。

鼻背は，鼻根部から鼻尖部までの経過部分を指す。鼻 屋部分は鼻背から煩部に移行する鼻背の両側面を指し,

鼻背との関係から, 鼻の立体構成を決定する要素となっ ている。この部分の発育が良好な鼻とは, 鼻屋の高さが あり，勾配が強い，一般にギリシャ鼻といわれるような 鼻を指す。

従来, 鼻背側面観の分類, 鼻屋の分類は, 肉眼観察で 行われてきた。

古川ら ${ }^{11}$ は, 正面観のモアレ縞走行の違いをもとに, 複 雑な曲面を描く外鼻を客観的に分類した。すなわち，鼻 背は, モアレ縞の間隔による分類, 鼻背両側斜面の鼻屋 部の立体的形態はモアレ縞の本数, 走行からの分類であ る。特に鼻屋は立体的曲線を描く部分であるため，モア レ縞を利用してその形態を分析することは有意義なこと
であると考える。

鼻背，鼻屋の分類型についてはフィリピン人女性外鼻 のモアレ縞の走行に，古川ら"104 分類型に相当しない 形態がみられたため,これをTYPE 5 として新たに加え 5 分類型に分類した ${ }^{19)}$ 。

TYPE 5 について詳細に述べると，TYPE 5 は，鼻背 のモアレ縞が鼻尖部付近に片寄り，丸みを帯びているも で，鼻根部から鼻背中央付近までの隆起が弱く，鼻筋の 通らない，そして，鼻背中央なら下方部分で急激に前方 へ突出している。すなわち, 鼻背から煩部への傾斜は緩 やかであり，外鼻下方の突出が強い形態である。鼻背の モアレ縞の分類から推察すると, TYPE 5 は TYPE 2 の 特殊型であり，鼻屋のモアレ縞の分類では，TYPE 1 の ように発達の悪い形態であると考えられた。

男性の TYPE 5 の出現率は $8.2 \%$ と低いが，女性では $30 \%$ と高く，男女間で有意差が認められている点から，

特に,フィリピン女性に多い形態と考えられた。

古川ら ${ }^{11}$ は, 肉眼観察による鼻背の分類型をモアレ縞 による鼻背の分類型に対応させて側面観の説明をしてい る。その内容は TYPE 1 は直線型, TYPE 2 は凹曲型, TYPE 3 は波状型, TYPE 4 は凸曲型および鈎状型に対 応するというものである。このことから，TYPE 5 は凹 曲型の特殊型であり，広義の意味では山曲型とすること ができる。

鼻背の出現率から, 男性は TYPE 1, 2 が多く, 女性 は TYPE 2, 5 に多い傾向がみられた。したがって, 古 川ら ${ }^{11} の$ 方法によるとフィリピン人男性は直線型と凹曲 型に代表され，女性は凹曲型に代表されていた。フィリ ピン人男女の鼻背形態の相違点は, 直線型の出現率であ ると考えられた。

鼻屋の発達程度による分類では，男女ともに TYPE 4 が多かった。つまりフィリピン人外鼻は，特に著明な走 行を示さないものが多かった。しかし，女性の場合は， 鼻屋の発達が悪いグループである TYPE 1, 5 の 2 分類 型の出現率が，全体の半数を占める点, TYPE 1, 5, 4に 性差が認められる点を考慮すると, 男性より鼻屋の発達 の悪い形態も多いと考えられた。

\section{2. 他の人種との比較}

フィリピン人の頭顔面部ならびに歯列弓形態の一連の

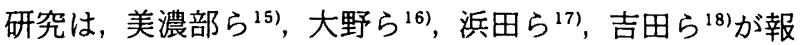
告している。これらの報告では, フィリピン人は, 日本 人と比較して, 頭顔面部においては頭部の発達が小さく, 顔面の幅が広い，特に下顎の側方部への発達が著しいと され，計測值では Atayal 族, Saisiyat 族に近似してい 


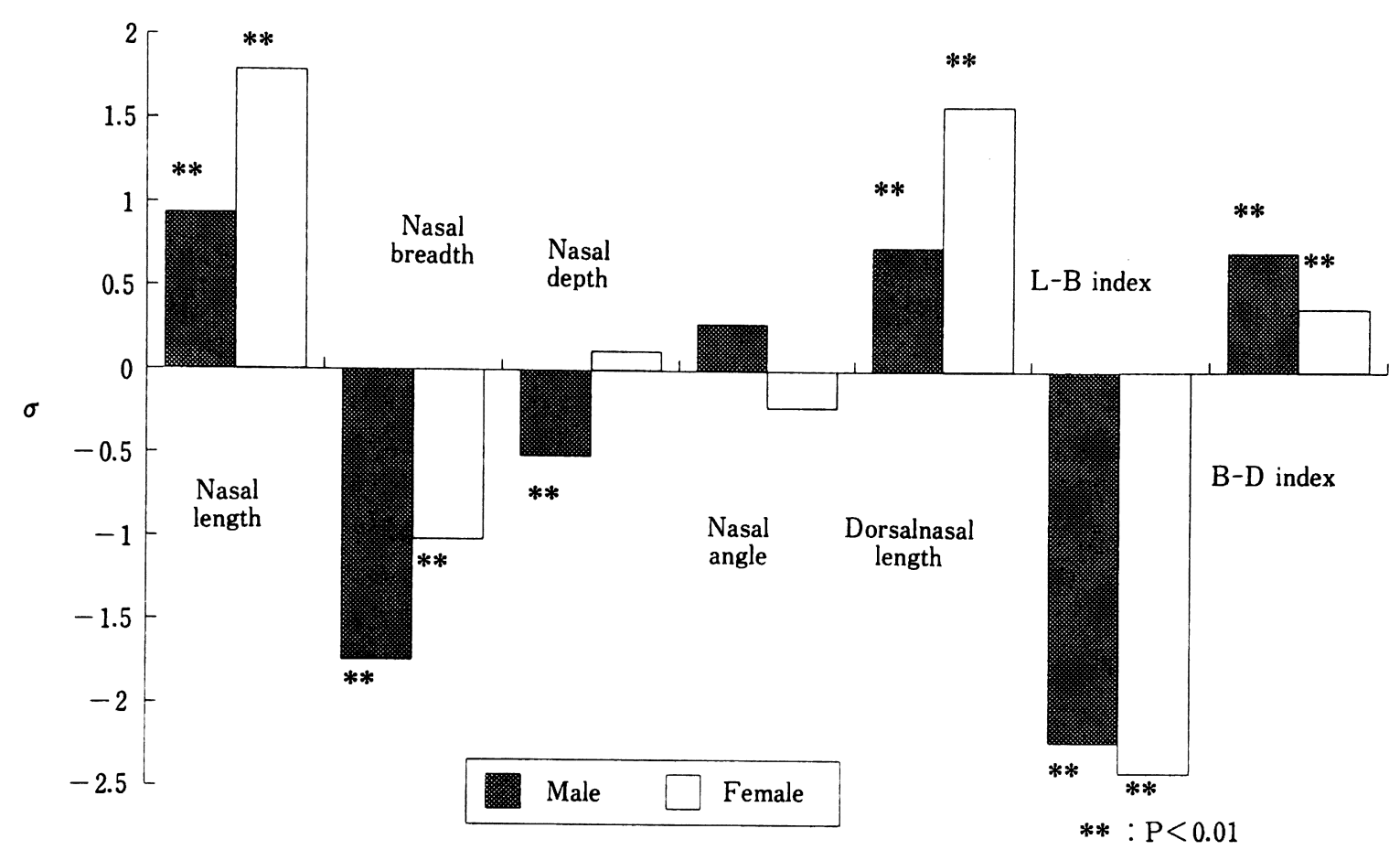

Fig. 4 The correlative standard deviation of Japanese. The criterion line shows means of Filipino.

Table 4 Factor loadings of principal component analysis.

\begin{tabular}{lrrr}
\hline & \multicolumn{1}{c}{$Z 1$} & \multicolumn{1}{c}{$Z 2$} & \multicolumn{1}{c}{$Z 3$} \\
\hline Nasal length & 0.556 & -0.256 & -0.258 \\
Nasal breadth & 0.31 & 0.513 & 0.661 \\
Nasal depth & 0.509 & 0.326 & 0.051 \\
Nasal angle & -0.075 & 0.718 & -0.661 \\
Dorsalnasal length & 0.574 & -0.224 & -0.239 \\
\hline
\end{tabular}

たと述べられている。歯列弓では，歯列弓長と歯列弓幅 の比率は, Atayal 族, Saisiyat 族と類似していたと報告 されている。

そこで，今回と同じ方法で研究した報告は日本人外 鼻 ${ }^{22}$ であるためこれを中心に比較するとともに肉眼観察 を主眼とした他の報告者による日本人，および台湾人の 結果とも比較検討した。

フィリピン人を基準として計測項目, 指数項目の関係 偏差を示した (Fig. 4)。フィリピン人は日本人と比較し て, 男女ともに鼻長, 鼻背長が小さく, 鼻幅が大きかっ た。フィリピン人の顔面は, 日本人ょり側方部への発達 が著し(15,16) との報告と考え合わせると, 顔の幅が広い のにつれて，鼻幅も広くなったのかとも考えられた。

日本人ょりフィリピン人の方が鼻長幅指数が顕著に大 きかった結果は, 鼻長, 鼻幅の 2 計測項目の差からくる
Table 5 Eigenvalue and contribution.

\begin{tabular}{lccl}
\hline & Z1 & Z2 & \multicolumn{1}{c}{ Z3 } \\
\hline eigenvalue & 2.633 & 1.140 & 0.879 \\
contribution & 0.527 & 0.228 & 0.176 \\
cumulative contribution & 0.527 & 0.755 & 0.93 \\
\hline
\end{tabular}

ものである。この 2 項目においてフィリピン人と日本人 の差に注目すると, 男性では, 鼻長の差より鼻幅の差が 大きく，女性では，鼻幅の差より鼻長の差が大きかった。 このことから, フィリピン人と日本人を比較した場合, 男性では鼻長より鼻幅の差が鼻長幅指数に影響を与え, 女性では鼻幅より鼻長の差が鼻長幅指数に影響を与えて いることが窅えた。

鼻深は男性は有意差があったが，女性では有意差はな かった。鼻深は, 鼻根部最陥山点から鼻尖点までのモア レ縞の本数から得たものである。したがって, 男性の鼻 深の差が鼻下点から鼻尖点までの突出の差によるもの か，それとも鼻根部の陥凹が強いことによるかは不明で あるが, フィリピン人の方が鼻の深さがあるといえる。

鼻背の矢状断面の角度は, 男性では日本人が大きく, 女性ではフィリピン人が大きかったが，両者とも有意差 は認められなかった。

鼻幅深指数は男女ともにフィリピン人より日本人の方 が大きかった。したがって, フィリピン人は日本人より 


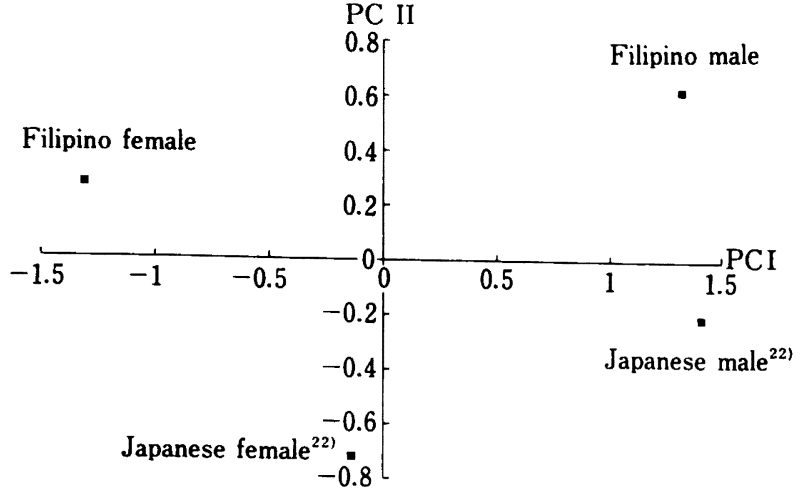

Fig. 5 Means of the principal component scores.

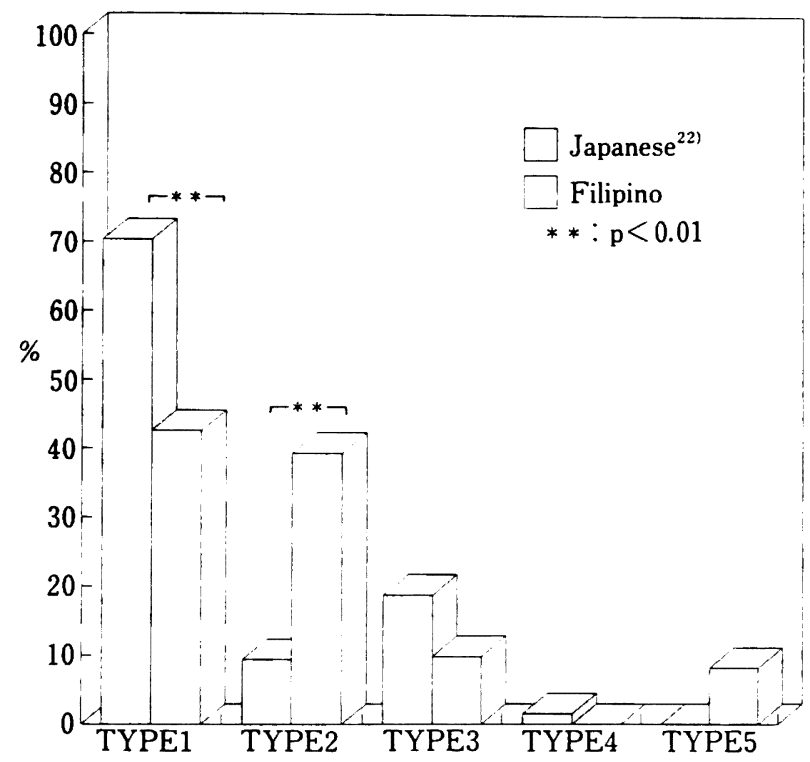

Fig. 6 Type of dorsalnose in male.

鼻幅に対して鼻梁が小さかった。

フィリピン人と日本人の鼻長, 鼻幅, 鼻深, 鼻背の矢 状断面の角度を用いて相関行列から主成分分析を行った (Table 4,5)。第一主成分は, 単位の異なる鼻背の矢状断 面の角度の因子負荷量が小さいことから，大きさを示す ものと思われる。第二主成分は長さ，第三主成分は幅を 示している。累積寄与率が第二主成分までで $75 \%$ であっ たことから、フィリピン人男女, 日本人男女の第一主成 分と第二主成分における主成分得点の平均值を座標に示 した（Fig. 5)。第一主成分から男性と女性が区分されて おり，第二主成分で人種差がほほ表現されていた。

鼻背のモアレ縞の間隔による分類では, フィリピン人 男性, 日本人男性ともに, TYPE 1 が最も多い点では一 致していた。しかし，フィリピン人男性の TYPE 1 と 2

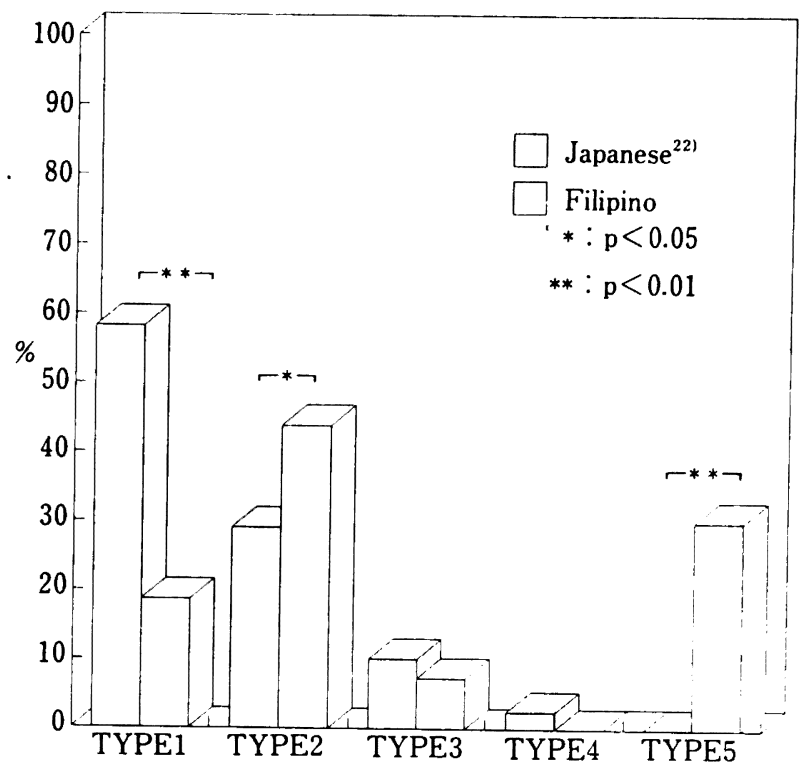

Fig. 7 Type of dorsalnose in female.

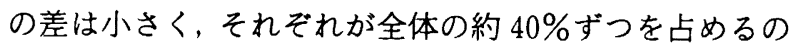
に対し, 日本人男性は TYPE 1 が全体の $70 \%$ を占めて, 両者の分類型の出現傾向は異なっていた。また, TYPE 1 はフィリピン人男性より日本人男性が有意に高い出現 率を示し, TYPE 2 はフィリピン人男性が日ー元人男性よ り有意に高い出現率を示した。したがって，フィリピン 人男性と日本人男性の相違点は, フィリピン人男性が直 線型と凹曲型の 2 種類に代表され, 日本人男性が直線型 に代表されていた点であった。

女性の場合の相違点は, フィリピン人女性の鼻背の形 態は，日本人女性より凹曲型とその特殊型の存在が多く， 日本人に多い直線型が少なかった点であった。

フィリピン人男女の特徵として, TYPE 4 が出現しな い。つまり，凸曲型，鈎状型が存在しなかったこともあ げられた。日本人には TYPE 5 は存在しなかった（Fig. $6,7)$ 。

過去の日本人男性の報告では, 加藤3), 古川ら ${ }^{111}$ は, 鼻 背の形態を 5 種類に分類し, 直線型が最も多かったと述 べている。増田 ${ }^{4}$, 猪口ら51は 4 種類に分類し, 直線型が

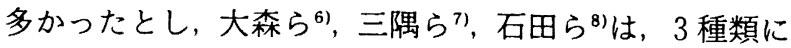
分類し、直線型が多かったと報告している。いずれの報 告も直接型がきわめて多いことから，日本人男性とフィ リピン人男性の鼻背の形態とは異なると思われた。

日本人女性に関して, 増田 ${ }^{4)}$, 猪口ら ${ }^{5)}$, 大森ら ${ }^{6)}$, 三隅 $ら^{7),}$ 石田 ${ }^{81}$ は直線型が多いと報告しており, フィリピ ン人の凹曲型が最も多い点と異なっていた。 許 ${ }^{23}$ は台湾人 Atayal 族の男性と女性の鼻背側面観を 


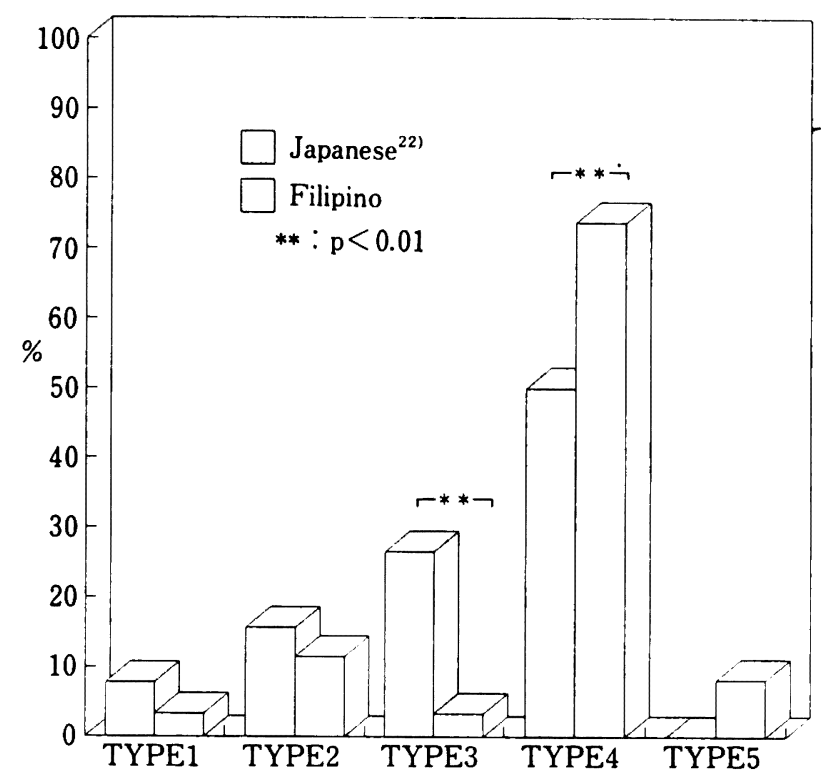

Fig. 8 Type of the roof of a nose in male.

凸, 直, 凹に分類し, 男性は直線型が約 $50 \%$ を占め, つ いで凹曲型が約 $40 \%$ みられたと報告し，女性は，大部分 を凹曲型が占めていると報告している。これらの報告か ら，フィリピン人は日本人の鼻形態より台湾人のそれ に類似していると思われた。

鼻背の形態に関しては，ヨーロッパ人のおよそ $40 \%$ が 直鼻，30\%が凸鼻，二ューヨークのユダヤ人では約 $60 \%$ が直鼻，13〜14\%が凸鼻，南米インディアンに直鼻が多 く，オーストラリア原住民, ブッシュマンでは凹がふつ うとされており ${ }^{13)}$, 南方系に凹が多いと思われた。このこ とからフィリピン人は, 南方系の特徴を持ち合わせてい ると考えられた。

鼻屋の発達程度による分類では, フィリピン人男性, 日本人男性ともに TYPE 4 が最も多く出現していた。し かし，TYPE 4 に関しては，フィリピン人男性が全体の 約 $75 \%$ を占めるのに対し, 日本人男性は $50 \%$ であり, 有 意差が認められた。女性も，フィリピン人，日本人とも に TYPE 4 が多かった。日本人女性は約 $70 \%$ TY TYE 4 であったが，フィリピン人女性は TYPE 4 が約 $45 \%$ であり，両者に有意差も認められた。フィリピン人は, 発達が悪い形態である TYPE 1,5 とを合計すると約 $50 \%$ 占めることから, 日本人女性より発達の悪い形態 が多かった。

男性では TYPE 1, 2 においてフィリピン人と日本人 との間に有意差が認められなかったが, 女性では TYPE 1 に有意差が認められなかったが, TYPE 2 において有 意差が認められた。TYPE 3 は，日本人男性の方がフィ

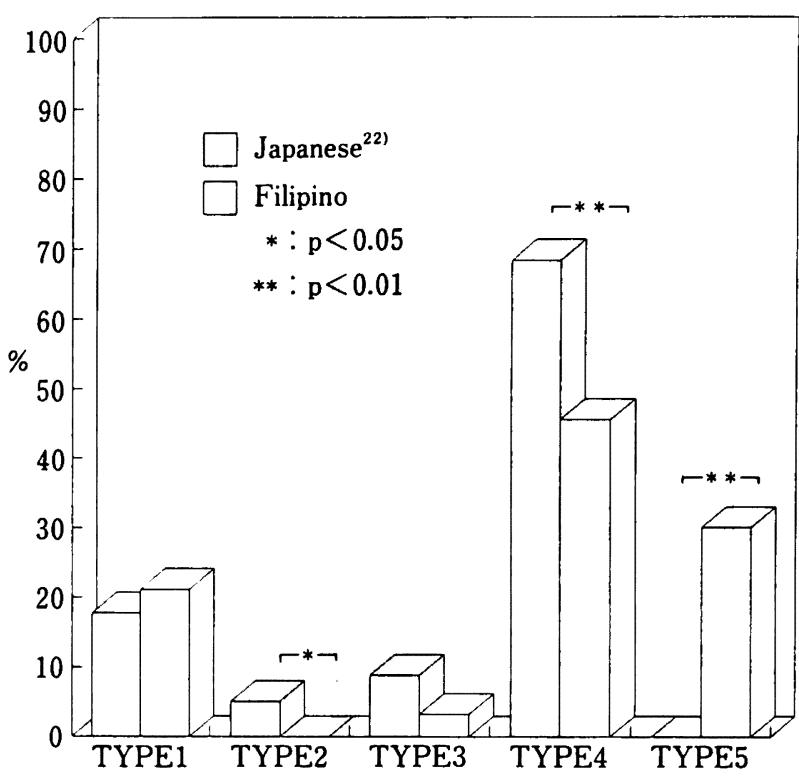

Fig. 9 Type of the roof of a nose in female.

リピン人男性より有意に高い出現率を示した。TYPE 5 はフィリピン人女性が日本人女性より有意に高い出現率 を示した。

つまり，男性では，フィリピン人，日本人ともに特に 著明なモアレ縞走行を示さない形態が多く，フィリピン 人ではそれが特徴的であったが，これに対し，日本人は 鼻屋の発達が良い鼻筋の通った形態も多かった。した がってこれらがフィリピン人男性と日本人男性の相違点 であった。

女性では, フィリピン人, 日本人ともに TYPE 4 が最 も多いが，フィリピン人は，日本人女性の場合のように 特に著明な走行を示さないモアレ縞が全体の $70 \%$ をし める点と異なり, 発達の悪い形態が多いことから, これ がフィリピン人女性と日本人女性の相違点であった (Fig. 8, 9)。

古川ら ${ }^{11}$ の日本人男性は TYPE 1〜3 は 10\%程度で, TYPE 4 が約 70\%ときわめて多く, TYPE 4 が多い点で はフィリピン人と同様であった。

北方系は鼻筋が通っているといわれる ${ }^{24)} と$ から，日 本人の外鼻は, この特徵に類似しているが, フィリピン 人の特徵とは異なっていると思われた。

指数による分類方法として鼻指数が一般的である。今 回, 調査した鼻長幅指数と若干異なるが, 人種差検討の 参考として，鼻指数の区分で鼻長幅指数の検討を行った。 鼻指数の区分は，狭鼻 69.9 以下, 中鼻は $70.0 \sim 84.5$, 広 鼻は85.0 99.0, 過広鼻は 100 以上である。狭鼻はコー カソイド，中鼻はモンゴロイド，広鼻はネグロイドに対 
Table 6 Observation of L-B Index.

n (\%)

\begin{tabular}{|c|c|c|c|c|}
\hline & leptorrhine & mesorrhine & chamaerrhine & hyperchamaerrhine \\
\hline & $55.0 \sim 69.9$ & $70.0 \sim 84.9$ & $85.0 \sim 99.9$ & $100<\mathrm{X}$ \\
\hline Japanese male ${ }^{22 l}$ & $11(18.03)$ & $48(78.69)$ & $2(3.28)$ & $0(0.00)$. \\
\hline Filipino male & $0(0.00)$ & $18(31.03)$ & $36(62.07)$ & $4(6.90)$ \\
\hline Japanese female ${ }^{22)}$ & $24(31.58)$ & $43(56.58)$ & $9(11.84)$ & $0(0.00)$ \\
\hline Filipino female & $1(0.86)$ & $26(22.41)$ & $64(55.18)$ & $25(21.55)$ \\
\hline
\end{tabular}

応しているといわれている

フィリピン人男性は, 中鼻から過広鼻に分布していた が，そのうち広鼻がもっと多くみられた。フィリピン人 女性は狭鼻から過広鼻に分布していたが，広鼻が最も多 かった。鼻長幅指数の平均值からもフィリピン人男女の 外鼻は広鼻に属していた (Table 6)。

増田 ${ }^{12)}$ は年齢別に日本人を調査し，中鼻が最も多いと 報告していることからも，日本人は中鼻に属すると考え られ、フィリピン人と日本人では鼻指数の区分から人種 差があると考えられた。

欠田 ${ }^{251}$ は, 福建系, 広東系漢族, タイヤル族, アミ族の 生体計測を行い, 各種族間の比較を行っている。鼻指数 の平均値は，いずれの種族の男女とも 60 から 66 の間を 示していた。したがって，これらは狭鼻に属していた。 許 ${ }^{23)}$ の報告した Atayal 族の鼻指数は，男女ともに中鼻 に最も高い出現率を示し, 鼻指数の平均值でも中鼻で あった。余 ${ }^{26)}$ の Atayal 族に関する報告でも同様の結果 であった。浜田 ${ }^{27)}$ の Atayal 族の鼻指数は, 男性 69.11, 女性 68.93 で狭鼻, Saisiyat 族は男性 76.92, 女性 70.01 で中鼻, 大森ら ${ }^{28)}$ の福建系台湾人は男性 66.76 , 女性 67.91 で狭鼻であった。台湾人は, 狭鼻から中鼻に属し, フィリピン人の広鼻とは異っていた。

南モンゴロイドの顔面の特徵として, 顔幅が広く, 輪 郭は丸く, しばしば突䫇, そして, 鼻は低く広く, 鼻孔 もつぶれたように左右に長いといわれている ${ }^{299}$, 埴原 ${ }^{241}$ は，モンゴロイドの顔貌を北方系，南方系とに分けた形 態を提唱しているが，これによると北方系の外鼻は鼻筋 が通った形態であるとしている。

計測部位が異るため明らかなことはいえないが, 鼻長 幅指数が広鼻に属することは, フィリピン人の外鼻が南 方系の特徵を備えていることを示唆していると考えた。

美濃部 ${ }^{30}$ は顔面のモアレ縞から, 上口唇部, 煩部の突出 度, 顔面パターン分類などフィリピン人の顔面形態を検 討し, フィリピン人の上口唇部は日本人と比較して, 前 方に突出していると報告している。本研究で得られた外 鼻の特徵と合わせると,フィリピン人の代表的側面観は,
鼻背が凹曲していて上口唇部が突出している形態とな る。また, フィリピン人の外鼻は低いとの一般的概念が 見受けられる。フィリピン人と日本人の結果では, 鼻染 はフィリピン人男性が有意に大きく，女性は有意差がみ られない, 鼻背の矢状断面の角度でも両者に有意差はみ られないなど, 外鼻の高低に関しては, 前述の概念は当 てはまらないようである。これは，基準の設定にもよる が, 外鼻と上口唇部の突出状態の関係から, フィリピン 人の外鼻は低いと判断されているのではないかとも考え られる。また, 美濃部 ${ }^{300}$ は比較デー夕が少ないことから断 定は出来ないと前置きしているが, フィリピン人顔面形 態は北方系と南方系の両者の特徵を備えていると述べて いる。本研究のフィリピン人男女の外鼻は, 日本人より 鼻長幅指数は大きく, 鼻幅深指数は小さい, 鼻背形態は 凹曲型が多い，鼻屋の発達が悪い形態が多いことから， 従来の報告と比較し推察すると, フィリピン人男女は南 方系の要素が強いと考えられた。

これに対し, 日本人男女の外鼻は, 中鼻に属し, 鼻筋 が通った形態をしているので, 北方系の要素を持つと思 われた。また, フィリピン人男性とフィリピン人女性を 比較すると, 鼻長幅指数, 鼻幅深指数の大きさ, 鼻背, 鼻屋の分類型の出現程度から, 男女ともに南方系の特徵 を備えているが，男性より女性の方が，より強い傾向を 持つことが示唆された。

\section{結＼cjkstart論}

モアレ縞を用いて，フィリピン人成人男女の外鼻の形 態について観察検討を行い, 次の結果を得た。

1.フィリピン人男性の鼻長, 鼻幅, 鼻背長, 鼻深は 女性より大きく，鼻背の矢状断面の角度は性差がなかっ た。フィリピン人男性は鼻幅に対する鼻深の大きさは女 性より大きかったが，鼻幅に対する鼻長は小さかった。

2.フィリピン人男性の鼻背の形態は, 直線型と山曲 型に代表されたが, フィリピン人女性は, 凹曲型に代表 された。また，凹曲型の特殊型は，フィリピン人に特有 
であったが，特に女性に多くみられた。

3. 鼻屋の発達度は, フィリピン人男性がフィリピン 人女性より良好であった。

4. 日本人と比較すると，フィリピン人は男女ともに 鼻幅が大きく鼻長が小さかった。

5. 鼻背の形態は, フィリピン人男女ともに日本人男 女より凹曲型が多かった。

6。鼻屋の発達度では，フィリピン人男性は，日本人 男性より，発達の良い形態が少なかった。フィリピン人 女性は日本人女性より, 発達の悪い形態が多かった。

7.フィリピン人の外鼻は男女とも南方系の特徵を備 えていたが，女性の方がょり南方系の傾向が強かった。

\section{文献}

1）山崎 清: 顔の人類学, pp. 404 416, 天佑書房, 東 京, 1943.

2) Martin, R. and Saller, K. : Lehrbuch der Anthropologie. pp. 401 413, Gustav Fisher verlag, Stuttgart, 1957.

3）加藤勤爾：本邦青年顔貌の側面観に就て。臨床歯科 $10: 292 \sim 300,1938$.

4) 増田 守: 九州日本人外鼻の人類学的研究. 熊本医 会誌 30：956〜1008， 1956.

5）猪口清一郎, 日高秀治, 馴松忠吉：外鼻（鼻根及び 鼻梁) 形態特にその地方差について。熊本医会誌 $33: 2665 \sim 2683,1959$.

6）大森忠雄, 宮崎道雄, 三枝 博, 净住瑞雄：外鼻 (鼻 根·鼻背)の形態について. 福岡歯大誌 $4: 367 \sim 376$, 1977.

7）三隅房邦，立花美之，宇野昭彦：熊本市住民外奥の 形態，熊本医会誌 $45 ： 857 \sim 875,1971$.

8）石田龍佑, 中川和芳, 井野慶一：五木村住民外悬の 形態. 熊本医会誌 $45 ： 876 \sim 894,1971$.

9）猪口清一郎, 日高秀治, 幡本利中：外鼻（鼻底部） 形態 特にその地方差について。 熊本医会誌 33 : 2684 2704, 1959

10）大森忠雄, 中村隆之, 大坪克安, 八尋純子, 浜田法 康, 净住瑞雄：外鼻（鼻底部）の形態について（そ の 1). 福岡歯大誌 $5: 63 \sim 72,1978$.

11）古川 明, 田中英雅, 鈴木 猛, 横澤賢樹、仲村啓 二, 宮澤富雄, 竹井哲司：モアレ縞による外鼻形態 の分類. 日大歯学 $56: 1083 \sim 1088 ， 1982$.

12）香月 武, 後藤昌昭, 川野芳春, 田代英雄, 蔵田副 雄：顔面モアレ写真の分析による外具の対称性の数 量化. 日蓋誌 $5: 145 \sim 153,1980$.

13）保志宏：人類学講座第 7 巻人種（寺田和夫 編), pp. 69〜 74, 雄山閣出版, 東京, 1977.
14）高橋 良：楀は何を語りたいのか. pp. 130〜141, 築 地書館, 東京, 1990 .

15）美濃部浩久, 若月英三, 伊藤浩昭, 大野二朗, 浜田 立太, 吉田佳子, 石森幹淑：フィリピン人成人男子 の頭部, 顔面形態の人類学的研究. 昭歯誌 9 : 419 429, 1989.

16）大野二朗, 若月英三, 伊藤浩昭, 美濃部浩久, 浜田 立太, 吉田佳子：フィリピン人成人女性の頭部, 顔 面形態の人類学的研究. 昭歯誌 $10: 46 \sim 54,1990$.

17）浜田立太, 吉田佳子, 伊藤浩昭, 美濃部浩久, 大野 二朗, 若月英三：フィリピン人成人男性の歯列弓の 形態と頭顔面部の人類学的研究. 成長 29 : 135 149, 1990.

18）吉田佳子, 伊藤浩昭, 美濃部浩久, 大野二朗, 浜田 立太, 若月英三：フィリピン人成人女性の歯列弓の 形態と頭顔面部の人類学的研究. 昭歯誌 11 : 208〜219, 1991.

19）吉田佳子, 近藤信太郎, 美濃部浩久, 大野二朗, 浜 田立太, 若月英三：女性の外鼻の形態について。昭 霜誌 $12 ： 348 \sim 354,1992$.

20） Turner, C. G.：歯が語るアジア民族の移動（埴原和 郎訳)。サイエンス 19：96〜103，1989.

21）嘉村壽人：モアレトポグラフィー法による日本人女 性と台湾人女性の顔面形態の比較. 九州歯会誌 43 : 263 282, 1989 .

22）吉田佳子, 近藤信太郎, 北村誠敏, 若月英三：日本 人外鼻の性差について. 昭歯誌 13：254〜261, 1993.

23）許 文政：台湾宜蘭県四季 Atayal 族の人類学的研 究. 長崎医誌 $45: 46 \sim 67,1970$.

24）埴原和郎：日本人の形成，(埴原和郎編）：日本人新 起源論, pp. 50 82, 角川選書, 東京, 1990 .

25）欠田早苗：台湾在住諸族の人類学的研究福建系。広 東系漢族ならびにタイヤル族，アミ族について，人 類誌 $82 ： 269 \sim 288,1974$.

26）余錦泉, 許文政, 黄 士情: 台湾宜蘭県楽水 Atayal 族の人類学的研究. 長崎医誌, 45:297 305, 1970 .

27）浜田法康, 内田雄康, 毛利達雄, 魏 賢治, 大森忠 雄：Atayal 族ならびに Saisiyat 族の頭・顔面部の 計測学的研究. 福岡歯会誌 $13: 257 \sim 268,1987$.

28）大森忠雄, 藤 英俊, 浜田法康, 中村隆之, 武井俊 哉, 魏 賢治, 吳 啓成, 羅 碧玲：福建系台湾人 の頭・顔面部および歯列の形態に関する研究，歯基 碳誌 $27: 27 \sim 38,1985$.

29）寺田和夫：人類学講座 第 7 巻 人種（寺田和夫 編), pp. 147 182, 雄山閣出版, 東京, 1977 .

30）美濃部浩久：モアレ縞による三次元的計測法を応用 したフィリピン人顔面の形態学的研究. 昭歯誌 12 : 325〜342, 1992. 